\title{
Ophthalmic Examinations External File Path
}

National Cancer Institute

\section{Source}

National Cancer Institute. Ophthalmic Examinations External File Path. NCI Thesaurus.

Code $C 162317$.

The literal identifier of an ophthalmic examination external file name. 